\title{
WYBRANE POTRZEBY EDUKACJI TERAPEUTYCZNEJ OSÓB Z DEMENCJĄ STARCZĄ ORAZ ICH RODZIN
}

\begin{abstract}
Streszczenie
Demencja zgodnie z klasyfikacją ICD-10, to zespół objawów spowodowanych przewlekła lub postępująca choroba mózgu, które manifestuja się zaburzeniami wyższych funkcji korowych, takich jak: pamięć, myślenie, orientacja, rozumienie, liczenie, postugiwanie się językiem oraz zdolność do uczenia się i oceny. Pomimo iż demencja nie jest cecha charakterystyczna dla procesu starzenia się, to jednak jej ryzyko wystapienia powaznie wzrasta wraz z wiekiem. Jest to nieuleczalna choroba przewlekła, zaliczana do wielkich problemów geriatrycznych, która wywotuje szereg negatywnych konsekwencji fizycznych, psychicznych i społecznych. Sama osoba chora na drodze edukacji terapeutycznej musi zostać wyposażona $w$ wiedzę $i$ umiejętności niezbędne do skutecznego samozarzadzania własna choroba (rozpoznawanie i monitorowanie objawów choroby, aktywna postawa $i$ petne zaangażowanie $w$ proces terapeutyczny, adaptacja do choroby i radzenie sobie z jej konsekwencjami, przestrzeganie zaleceń lekarskich itp.). Jak wiadomo demencja jest choroba postepujaca, która może doprowadzić do catkowitej niepetnosprawności chorego a co za tym idzie konieczności sprawowania całodobowej opieki przez osoby drugie. Biorąc pod uwage iz opiekunami osób chorujacych na demencje sa przede wszystkim członkowie najbliższej rodziny (głównie wspótmatżonek lub dzieci) pojawia się silna potrzeba edukacji terapeutycznej tych osób. Obszary edukacji powinny dotyczyć na przykład zagadnień związanych z istota choroby, metodami opieki pielegnacyjnej, podaża leków, zarządzaniem

* Anna Mirczak - dr n. medycznych, adiunkt w Katedrze Gerontologii Społecznej, Instytutu Pracy Socjalnej Uniwersytetu Pedagogicznego im. Komisji Edukacji Narodowej w Krakowie.
\end{abstract}


bólem oraz umiejętnościq radzenia sobie ze stresem $w$ profilaktyce wypalenia opiekuna. Choroby przewlektej takiej jak demencja nie da się wyleczyć, ale za pomoca edukacji zdrowotnej można ja skutecznie kontrolować. Celem pracy byto przedstawienie problemów i zagadnień, które należy podjać w toku edukacji terapeutycznej pacjentów z demencją starcza i ich rodzin.

Slowa kluczowe: otepienie, edukacja terapeutyczna, osoba starsza, opieka nieformalna

\section{Wprowadzenie}

W związku z obserwowanym od dłuższego czasu zjawiskiem starzenia się społeczeństwa w Polsce i na świecie, przybywa osób w wieku starszym. W 2014 roku liczba osób w wieku 60 lat i powyżej wynosiła w Polsce pond $8 \mathrm{mln}(22 \%)$ w porównaniu do 5,6 mln seniorów (15\%) na początku lat 90 . ubiegłego wieku1. Wraz z wiekiem wzrasta ryzyko występowania lub współwystępowania wielu chorób przewlekłych, które ograniczają sprawność funkcjonalną seniora, a z czasem prowadzą do całkowitej zależności od opieki i pomocy osoby drugiej. Jedną z tych chorób może być otępienie (inaczej demencja), która zgodnie z definicją Światowej Organizacji Zdrowia (WHO) oznacza zespół objawów występujących w konsekwencji postępującej lub przewlekłej choroby mózgu². W klasyfikacji otępienia najczęściej stosuje się następujący podział:

- Otępienie pierwotne zwyrodnieniowe (choroba Alzheimera, otępienie czołowo-skroniowe, choroba Parkinsona, choroba Huntingtona, choroba z rozsianymi ciałami Lewy'ego). Jedną z najczęstszych przyczyn otępienia w wieku starszym jest choroba Alzhaimera ${ }^{3}$.

- Otępienie wtórne zwyrodnieniowe (np.: otępienia naczyniowe, otępienia w przebiegu zaburzeń metabolicznych, otępienie spowodowane używaniem alkoholu lub substancji psychoaktywnych, otępienia wywołane

\footnotetext{
1 GUS, Notka informacyjna przygotowana na posiedzenie Sejmowej Komisji Polityki Senioralnej dotyczace ,, Informacji Ministra Zdrowia na temat wptywu zmian demograficznych $i$ starzenia się społeczeństwa na organizację systemu ochrony zdrowia i Narodowy Program Zdrowia" (w dniu 19.02.2016 r.).

2 WHO, Dementia a public health priority..., dz. cyt., s. 1.

3 T. Gabryelewicz, Epidemiologia otępień i choroby Alzheimera na świecie i w Polsce, „Nowe Perspektywy w Leczeniu Choroby Alzheimera” 1998, s. 2-3.
} 
uszkodzeniem mózgu w następstwie urazu, otępienia w przebiegu pierwotnych i przerzutowych guzów mózgu) ${ }^{4}$.

Wśród symptomów otępienia wymienia się zaburzenia pamięci, orientacji w czasie i przestrzeni, myślenia, uczenia, liczenia, rozumienia, funkcji językowych, obniżoną motywację oraz zaburzenia zachowania i emocji ${ }^{5}$. Powyższe zaburzenia poznawcze mogą znacząco ograniczyć możliwości samodzielnego funkcjonowania w życiu codziennym osoby chorej a wraz z progresją choroby doprowadzić do całkowitej niesprawności chorego. W konsekwencji, osoba chora musi zostać objęta całodobową opieką osób drugich celem zaspokojenia podstawowych potrzeb życiowych takich jak: odżywianie, utrzymanie higieny własnej i otoczenia, ubieranie, komunikowanie itp. Opieka nad bliskim członkiem rodziny $\mathrm{z}$ otępieniem wymaga całkowitego przeorganizowania dotychczasowego życia a opiekunem najczęściej pozostaje najbliższa rodzina (żona/mąż lub dzieci) ${ }^{6}$. Zazwyczaj opiekun wraz z postępem choroby i coraz liczniejszymi obowiązkami pielęgnacyjno-opiekuńczymi, zmuszony jest do zaprzestania aktywności zawodowej, co w konsekwencji może pogorszyć jego sytuację finansową oraz zwiększyć ryzyko izolacji społecznej. Wraz z pogłębiającymi się zaburzeniami poznawczymi w wyniku demencji, sprawowanie opieki staje się coraz trudniejsze i obciążające. U chorego pojawiają się zaburzenia zachowania (agresja, depresja, lęk, niechęć do przyjmowania posiłków, brak higieny ciała i otoczenia i wiele innych), które stanowią źródło wielu narastających problemów i potrzeb opiekuńczych. Jedną $\mathrm{z}$ metod a raczej podstaw sprawowania adekwatnej opieki w chorobach przewlekłych, jest edukacja terapeutyczna. Zgodnie z definicją Światowej Organizacji Zdrowia (WHO), jest to proces umożliwiający pacjentowi przewlekle choremu i jego rodzinie samozarządzać zdiagnozowaną jednostką chorobową, zapobiegać powikłaniom oraz utrzymywać lub podnosi jakość życia?. Samozarządzanie (z ang. self-management) oznacza: zdolność jednostki do rozpoznawania i monitorowania objawów choroby, aktywną postawę i pełne zaangażowanie w proces terapeutyczny, adaptację do choroby i radzenie sobie z jej konsekwencjami, umiejętność postępowania w sytuacjach nagłych (zaostrzeń choroby), przestrzeganie zaleceń

\footnotetext{
4 A. Kiejna, P. Pacan, E. Trypka, T. Sobów, T. Parnowski, i inni, Standardy leczenia otepień, „Psychogeriatria Polska” 2008, nr 5(2), s. 59-94.

5 WHO, Dementia a public health priority, Geneva 2012.

6 L.N. Gitlin, R. Schulz, Family caregiving of older adults, w: Public Health for an aging society, red. R.T. Prohaska, L.A. Anderson, R.H. Binstock, The Johns Hopkins University Press, Baltimore, MD 2012, s. 181-204.

7 WHO, Therapeutic patient education. Continuing education programs for health care providers in the field of prevention of chronic diseases, Copenhagen1998.
} 
lekarskich oraz umiejętność zmiany obecnego stylu życia w profilaktyce powikłań choroby przewlekłej ${ }^{8}$. W związku z postępującym charakterem choroby otępiennej, zadania związane z samozarządzaniem chorobą od początku dotyczą także opiekunów a z czasem są wykonywane wyłącznie przez nich.

W zakładach opieki zdrowotnej edukacja terapeutyczna zazwyczaj jest prowadzona przez lekarza lub pielęgniarkę. Jednakże edukatorami zdrowia nie musi być tylko personel z wykształceniem medycznym, ale również osoby z inną profesją (psycholog, pedagog, pracownik socjalny) posiadające niezbędne przeszkolenie z zakresu edukacji zdrowotnej. W piśmiennictwie polskim dużo jest poradników dla rodzin sprawujących opiekę nad osobą z demencją (szczególnie chorującą na chorobę Alzhaimera). Zawierają one szereg przydatnych informacji z zakresu pielęgnacji, możliwości wsparcia, rehabilitacji medycznej i społecznej i wiele innych. Brakuje natomiast publikacji, które koncentrowałyby się głównie na potrzebach edukacji terapeutycznej osób z demencją oraz ich rodzin, która stanowi podstawę radzenia sobie z chorobą zarówno dla chorego (w początkowej fazie choroby) jak również dla osób sprawujących opiekę. Edukacja terapeutyczna w schorzeniach przewlekłych bywa nazywana fundamentem metodologicznym leczenia9. W literaturze naukowej problematyka edukacji terapeutycznej poruszana jest w kontekście różnych chorób przewlekłych takich jak: cukrzyca, nadciśnienie tętnicze krwi, astma oskrzelowa, otyłość, choroby dermatologiczne, AIDS i wiele innych.

\section{Cel pracy i metodologia}

Celem pracy było przedstawienie problemów i potrzeb, które należy podjąć w toku edukacji terapeutycznej pacjentów z demencją starczą i ich rodzin.

Praca powstała w oparciu o przegląd bazy czasopism recenzowanych takich jak PubMed i EBSCO oraz przegląd wyszukiwarki internetowej Google z usługą Google Scholar. Do wyszukania artykułów zastosowano słowa kluczowe w języku polskim takie jak: otepienie, osoby starsze, edukacja terapeutyczna, edukacja zdrowotna, opieka nieformalna oraz słowa kluczowe w języku angielskim takie jak: dementia, older people, therapeutic education, educational needs assessment, caregivers. Dodatkowo, przeanalizowano także rozdziały zamieszczone w podręcznikach dotyczących poruszanej problematyki.

\footnotetext{
8 J. Barlow, C. Wright, J. Sheasby, A. Turner, J. Hainsworth, Self-management approaches for people with chronic conditions: a review, „Patient Education and Counseling” 2002, nr 48(2), s. 177-187.

9 J. Tatoń, Edukacja terapeutyczna osób z cukrzyca - fundament metodologiczny leczenia, w: Diabetologia, red. J. Tatoń, A. Czech, PZWL, Warszawa 2001.
} 


\section{Zasady edukacji terapeutycznej w demencji starczej}

W związku z progresją choroby otępiennej, czego wyrazem są narastające zaburzenia poznawcze a później całkowita zależność osoby chorej od opiekuna, edukacja terapeutyczna od samego początku musi być kierowana zarówno do pacjenta jak również do osób z jego najbliższego otoczenia. Proces edukacji terapeutycznej należy rozpocząć od diagnozy potrzeb edukacyjnych pacjenta i jego rodziny (ustalenie co pacjent i jego rodzina wie na temat otępienie). Następnie, w oparciu o rozpoznane potrzeby (deficyt wiedzy i umiejętności w zakresie zdiagnozowanej jednostki chorobowej) należy przygotować plan edukacji.

Edukacja terapeutyczna osoby we wstępnej fazie choroby otępiennej (osoby samodzielne, bez nasilonych deficytów poznawczych) powinna obejmować zagadnienia związane z:

- Patofizjologią choroby, objawami, rokowaniem oraz przebiegiem procesu leczenia. Obecnie zaleca się aby pacjent z rozpoznanym otępieniem został poinformowany o diagnozie ${ }^{10}$.

- Ukazaniem pacjentowi jego roli w procesie samozarządzania rozpoznaną jednostką chorobową. Ukazaniem konieczności zmiany dotychczasowego stylu życia tj.: konieczność pomocy ze strony osób drugich w wykonywaniu czynności dnia codziennego, przygotowanie środowiska domowego (odpowiednie oświetlenie i oznakowanie mieszkania, niwelacja wystających elementów podłogi w profilaktyce upadków itp.)

- Profilaktyką powikłań (ukazanie konieczności utrzymywania aktywności fizycznej i społecznej) ${ }^{11}$.

Edukacja terapeutyczna rodziny pacjenta $\mathrm{z}$ demencją, czyli przekaz wiedzy i rozwijanie umiejętności dotyczących opieki musi uwzględniać możliwości poznawcze opiekuna. Oznacza to, że forma, zakres i tempo przekazu treści musi być dostosowana do jego możliwości percepcyjnych, dotychczasowej wiedzy i doświadczenia. We wstępnej fazie edukacji terapeutycznej należy wyjaśnić rodzinie pacjenta ogólnie istotę choroby (objawy, przebieg, rokowanie, leczenie). Jednoczenie rodzinę pacjenta należy uwrażliwić na potrzeby i problemy podopiecznego, które będą się stopniowo pojawiać i zaostrzać wraz z progresją

10 Department of Health, Reference Guide to Consent for Examination or Treatment, London 2001, www.dh.gov.uk/assetRoot/04/01/90/79/04019079.pdf. (dostęp 15.08.2017 r.).

1 National Collaborating Centre for Mental Health, Dementia: A NICE-SCIE guideline on supporting people with dementia and their carers in health and social care, British Psychological Society, UK 2007. 
choroby. Ponadto, należy wyjaśnić rodzinie, iż w opiece nad osobą z otępieniem należy kierować się następującymi zasadami:

- Człowiek z otępieniem pozostaje wciąż autonomiczną jednostką.

- Człowiek z otępieniem ma takie potrzeby jak inni.

- Człowiek z otępieniem jest tak samo wartościową osoba jak inni.

- Człowiek z otępieniem może być zdrowy i szczęśliwy.

- Drobne zmiany mogą mieć dużą wartość praktyczną.

- Zawsze pozostaje coś co można zrobić żeby pomóc ${ }^{12}$.

Dalsza edukacja terapeutyczna rodziny pacjenta $\mathrm{z}$ demencją starczą powinna obejmować takie zagadnienia jak:

- Przygotowanie mieszkania dla potrzeb osoby chorującej na demencję. Wraz z progresją choroby i pogłębiającymi się zaburzeniami poznawczymi, osoba chora może być narażona $\mathrm{w}$ dotychczasowym mieszkaniu na wiele niebezpieczeństw. Problemem staje się obsługa wielu urządzeń np. kuchenek gazowych i elektrycznych. Zwiększając bezpieczeństwo chorego, należy na stałe lub czasowo odciąć źródło zasilania (w zależności jak długo osoba chora przebywa samotnie w mieszkaniu). Następnie należy usunąć wystające elementy podłogi (dywany, progi itp.) celem prewencji upadkom. Dodatkowo, ważnym jest zadbanie o odpowiednią nawierzchnię podłogi (antypoślizgową) oraz właściwe oświetlenie pomieszczeń, w których przebywa chory. Ponadto, $\mathrm{z}$ otoczenia seniora $\mathrm{z}$ otępieniem powinno się usunąć wszelkie niebezpieczne przedmioty tj.: ostre noże, zapałki, materiały łatwopalne, leki itp.) oraz zabezpieczyć okna i drzwi wejściowe. Istotnym jest także zastosowanie w mieszkaniu pewnych oznakowań, które będą ułatwiać osobie chorej orientację w przestrzeni. Przeciwdziałając natomiast dezorientacji, z otoczenia chorego należy usunąć nadmiar rzeczy i bibelotów ${ }^{13}$.

- Edukacja dotycząca komunikacji z osobą z chorobą otępienną. Proces komunikacji jest jednym z ważniejszych aspektów życia każdego człowieka, pozwala bowiem wyrażać swoje opinie, myśli i potrzeby. Porozumiewanie się z osobą z otępieniem obarczone jest wieloma trudnościami. Należą do nich: problemy z rozumieniem przekazywanych komunikatów (stopniowe zanikanie rozumienia poszczególnych słów), trudności z wyrażaniem myśli i potrzeb na skutek zubożenia języka, wielokrotne powtarzanie tych samych zdań i wiele innych. Trudności w komunikacji są istotnym problemem zarówno dla chorego jak i jego rodziny. Osoba chora, nie mogąc wyrazić

12 P.V. Rabins, C.G. Lyketsos, C.D. Practical dementia care, OUP USA, 2006, s. 76.

13 Ibidem, s. 101. 
swoich potrzeb czuje się nierozumiana a w konsekwencji nerwowa i agresywna. Natomiast opiekun, który nie może zrozumieć przekazywanych przez podopiecznego komunikatów może mieć wrażenie tracenia kontaktu i więzi oraz poczucia winy, że nie może we właściwy sposób pomóc osobie najbliższej. Wychodząc naprzeciw tym problemom, opiekun powinien być przeszkolony z najprostszych metod komunikacji werbalnej i pozawerbalnej z osobą cierpiącą na demencję. Do najuważniejszych zasad takiej komunikacji należy: utrzymywanie kontaktu wzrokowego, używanie prostych i nierozbudowanych zdań, wolne tempo przekazu informacji, $\mathrm{w}$ razie potrzeby wielokrotne powtarzanie tych samych komunikatów, cierpliwość, życzliwość, wyrozumiałość, pozytywna postawa (uśmiech), usuwanie bodźców zakłócających komunikację (np. wyłączenie radia, TV), odwracanie uwagi chorego od sytuacji stresującej, gestykulowanie, uważne słuchanie i wiele innych ${ }^{14}$.

- Problemy pielęgnacyjne seniora chorującego na demencję. W tej grupie jest wiele zagadnień, które związane są z postępującymi zaburzeniami psychicznymi i fizycznymi osoby chorej. W celu minimalizowania stresu związanego z wykonywaniem czynności pielęgnacyjnych, opiekun powinien być merytorycznie i praktycznie przygotowany na pojawianie się potencjalnych trudności w tym zakresie. Podstawowym problemem pielęgnacyjnym będą kwestie związane z utrzymaniem higieny ciała i otoczenia chorego. Osoby z demencją niechętnie się myją, odmawiając tej czynności wielokrotnie, najczęściej w obawie przed wychłodzeniem ciała. Ponadto, ze względu na postępujące zaburzenia pamięci, senior wraz z progresją choroby przestaje rozpoznawać czynności higieniczne (mycie ciała, zębów/protezy, włosów itp.) jako znane. Zmuszanie do zabiegów higienicznych (czego należy się wystrzegać) może skutkować agresją fizyczną i psychiczną ze strony osoby chorej jako reakcja na stres. Drugim ważnym problemem są trudności z przyjmowaniem pokarmów (odpowiednie odżywienie). W przypadku osób z demencją starczą problem ten spotęgowanym jest dwukrotnie. Raz z powodu choroby a drugi w konsekwencji postępującego procesu starzenia się organizmu i pojawiających się zaburzeń łaknienia. Osoby z demencją bardzo często odmawiają przyjmowania wszelakich pokarmów. Jest to duże obciążenie opiekuńcze (każdy bowiem wie, że do życia potrzebne jest jedzenie i piecie) które wymaga od opiekunów wypracowania własnej „,metody" przekonywania i spokojnego zachęcania podopiecznego do spożycia

14 T. Adams, J. Manthorpe, Dementia Care: An Evidence based Textbook, CRC Press, London 2003, s. 148. 
przygotowanego posiłku (w razie konieczności należy rozważyć karmienie). Ponadto opiekun powinien wziąć pod uwagę inne przyczyny nie przyjmowania przez podopiecznego pokarmów (dolegliwości bólowe, zaparcia, brak uzębienia, trudności w przełykaniu). W profilaktyce niedożywienia, należy monitorować masę ciała chorego oraz ilość i jakość przyjmowanych posiłków. Kolejnym problemem będą trudności z samodzielnym ubieraniem się adekwatnym do pory roku. Czynności te wymagają nadzoru lub całkowitej kompensacji ze strony opiekuna. Uciążliwe zarówno dla pacjenta jak i opiekuna są także pojawiające się trudności z zaspakajaniem potrzeb fizjologicznych (nietrzymanie moczu i stolca, zanieczyszczanie otoczenia). Problemem pielęgnacyjnym będzie także zarządzanie lekami. Opiekun osoby z demencją starczą musi być przygotowany do tego, iż podopieczny może zapomnieć zażyć lub przedawkować wskazaną dawkę leków. Dlatego też, podaż leków powinna być pod ścisłym nadzorem opiekuna, który będzie znał alternatywne metody i drogi podania odpowiednich medykamentów w razie gdy np. podopieczny odmowi przyjęcia wskazanych leków lub pojawią się zaburzenia połykania ${ }^{15}$.

- Postępowanie w sytuacjach nagłych tj. sytuacji wynikających ze stopniowego pogarszania się stanu zdrowia lub nieprzewidzianych zdarzeń np. zadławienie, upadek itp. Ważne aby opiekun został przeszkolony z zakresu udzielania pierwszej pomocy (resuscytacja krążeniowo-oddechowa) w stanach zagrożenia życia.

- Edukacja dotycząca istniejących form wsparcia dla opiekunów nieformalnych jako profilaktyka wypalenia (z ang. burn out syndrome). Opieka nad osobą z chorobą otępienną to dwudziestoczterogodzinny dyżur trwający nieprzerwanie przez kilka lat. Zakres sprawowanych czynności i wykonywanych zadań stanowi duże obciążenie fizyczne i psychiczne dla opiekuna. Wymaga zaprzestania wielu dotychczasowych aktywności na rzecz podopiecznego i sprawowanej opieki. Praca ta obarczona jest dużym ryzykiem wypalenia dla opiekuna ${ }^{16}$. Oprócz edukacji terapeutycznej, której celem jest wyposażyć rodzinę/opiekuna pacjenta w odpowiednią wiedzę i umiejętności zarządzania chorobą przewlekłą, ważnym jest ukazanie opiekunom możliwości korzystania z zasobów wsparcia z zewnątrz. Pomocne są istniejące w Polsce organizacje, o których szczegółowe informacje można znaleźć

15 G. Berg, The importance of food and mealtimes in dementia care: the table is set, Jessica Kingsley Publishers, London 2006.

16 Alzheimer's Association, Alzheimer's Disease Facts and Figures, „Alzheimer's \& Dementia" 2014, nr 10(2), s. 1-46. 
w Internecie. Warto także korzystać ze wsparcia osób, które zmagają się z podobnymi problemami poprzez uczestnictwo w lokalnych spotkaniach grup wsparcia ${ }^{17}$.

- Podtrzymywanie aktywności fizycznej i społecznej podopiecznego. Ważnym w sprawowanej opiece jest wspieranie osoby chorej w jak najdłuższym utrzymywaniu samodzielności w zakresie czynności dnia codziennego (unikanie wyręczania). Istotna jest także codzienna rehabilitacja, terapia zajęciowa (poprzez taniec, śpiew, malarstwo, muzykę, zabawę i wiele innych) oraz trening umysłowy stymulując funkcje językowe oraz funkcje poznawcze) $)^{18}$.

- Edukacja dotycząca prawnych i finansowych aspektów sprawowanej opieki (odbieranie emerytury, zarządzanie kontem bankowym, zdolność do wyrażania świadomej zgody, prawo własnościowe itp.) prowadzona w konsultacji z prawnikiem. Szczególnie istotna w momencie kiedy podopieczny przestaje być świadomy podejmowanych decyzji.

\section{Podsumowanie}

Opiekę nad pacjentem z otępieniem w większości przypadków sprawuje rodzina pacjenta co potwierdza wiele badań ${ }^{19}$. Jest to niezwykle trudny proces wymagający wielkiego nakładu sił fizycznych i psychicznych ze strony opiekunów nieformalnych. Bowiem opieka nad osobą z otępieniem nie oznacza tylko wykonywania zadań wspierających lub całkowicie kompensujących czynności utraconych przez chorego (mycie, jedzenie itp.), lecz oznacza również rezygnację z dotychczasowego życia i prowadzonych aktywności przez opiekuna. Ze względu na postępujący charakter choroby i pogarszający się stan chorego, dodatkowym obciążeniem dla rodziny pacjenta bywa często brak wystarczającej wiedzy i umiejętności do sprawowania takiej całodobowej opieki. Dlatego też, aby zminimalizować stres związany z opieką oraz przeciwdziałając zjawisku wypalenia, przede wszystkim personel opieki zdrowotnej od początku, czyli od momentu zdiagnozowania choroby, powinien udzielać rodzinie chorego wsparcia informacyjnego poprzez edukację terapeutyczną. Dotychczasowe badania pokazują, iż znajomość istoty choroby otępiennej, jej objawów, leczenia oraz wpływu na funkcjonowanie chorego

17 T. Adams, J. Manthorpe, Dementia Care..., dz.cyt., s. 6.

18 P. Scileppi Kenneth, Jak opiekować się rodzicami którzy kiedyś opiekowali się Tobą, Wydawnictwo Bellona, Warszawa 2008.

19 H. Brodaty, M. Donkin, Family caregivers of people with dementia, „Dialogues in Clinical Neuroscience" 2009, nr 11, s. 217-228. 
przez opiekunów zwiększa poczucie pewności siebie w sprawowanej opiece oraz minimalizuje stres związany z przeciążeniem sprawowaną opieką ${ }^{20,21}$.Dodatkowo, dla osoby z otępieniem ważna jest przewidywalność, czyli stały rytm dnia i niezmienne otoczenie. Właściwy sposób sprawowania opieki daje szansę osobie z chorobą otępienną na dobrą jakość życia pomimo zdiagnozowanej jednostki chorobowej. Z kolei znajomość zasad opieki oraz potencjalnych problemów i potrzeb podopiecznego jest ważnym elementem profilaktyki wypalenia opiekunów. Przedstawiona praca nie wyczerpuje jednak tematu a stanowi raczej prezentację wybranych problemów z zakresu edukacji terapeutycznej osób z demencją starczą i ich rodzin.

\section{Bibliografia}

Adams T., Manthorpe J., Dementia Care: An Evidence based Textbook, CRC Press, London 2003.

Alzheimer's Association, Alzheimer's Disease Facts and Figures, „Alzheimer's \& Dementia" 2014, nr 10(2), s. 1-46.

Barlow J., Wright C., Sheasby J., Turner A., Hainsworth J., Self-management approaches for people with chronic conditions: a review, „Patient Education and Counseling" 2002, nr 48(2), s. 177-187.

Berg G., The importance of food and mealtimes in dementia care: the table is set, Jessica Kingsley Publishers, London 2006.

Blieszner R., Roberto K.A., Care partner responses to the onset of mild cognitive impairment. [Comparative Study Multicenter Study Research Support, NonU.S. Gov't], ,The Gerontologist” 2010, nr 50(1), s. 11-22.

Brodaty H., Donkin M., Family caregivers of people with dementia, „Dialogues in Clinical Neuroscience" 2009, nr 11, s. 217-228.

Department of Health, Reference Guide to Consent for Examination or Treatment, London 2001, www.dh.gov.uk/assetRoot/04/01/90/79/04019079.pdf. (dostęp 15.08.2017 r.).

Gabryelewicz T., Epidemiologia otępień i choroby Alzheimera na świecie i w Polsce, „Nowe Perspektywy w Leczeniu Choroby Alzheimera” 1998, s. 2-3.

20 R. Blieszner, K.A. Roberto, Care partner responses to the onset of mild cognitive impairment. [Comparative Study Multicenter Study Research Support, Non-U.S. Gov't], „The Gerontologist” 2010, nr 50(1), s. 11-22.

${ }^{21}$ K. Hepburn, M. Lewis, J. Tornatore, C.W. Sherman, K.L. Bremer, The Savvy Caregiver Program: The demonstrated effectiveness of a transportable dementia caregiver psychoeducation program, ,Journal of Gerontological Nursing” 2007, s. 30-36. 
Gitlin L.N., Schulz R., Family caregiving of older adults, w: Public Health for an aging society, red. R.T. Prohaska, L.A. Anderson, R.H. Binstock, The Johns Hopkins University Press, Baltimore, MD 2012, s. 181-204.

GUS, Notka informacyjna przygotowana na posiedzenie Sejmowej Komisji Polityki Senioralnej dotyczace „Informacji Ministra Zdrowia na temat wptywu zmian demograficznych $i$ starzenia się spoleczeństwa na organizację systemu ochrony zdrowia i Narodowy Program Zdrowia" (w dniu 19.02.2016 r.).

Hepburn K., Lewis M., Tornatore J., Sherman C.W., Bremer K.L., The Savvy Caregiver Program: The demonstrated effectiveness of a transportable dementia caregiver psychoeducation program, „Journal of Gerontological Nursing” 2007, s. 30-36.

Kiejna A., Pacan P., Trypka E., Sobów T., Parnowski T., i inni, Standardy leczenia otępień, „Psychogeriatria Polska” 2008, nr 5(2), s. 59-94.

National Collaborating Centre for Mental Health, Dementia: A NICE-SCIE guideline on supporting people with dementia and their carers in health and social care, British Psychological Society, UK 2007.

Rabins P.V., Lyketsos C.G., Practical dementia care, OUP USA, 2006.

Scileppi Kenneth P., Jak opiekować się rodzicami którzy kiedyś opiekowali się Toba, Wydawnictwo Bellona, Warszawa 2008.

Tatoń J., Edukacja terapeutyczna osób z cukrzyca - fundament metodologiczny leczenia, w: Diabetologia, red. J. Tatoń, A. Czech, Wydawnictwo Lekarskie PZWL, Warszawa 2001.

WHO, Dementia a public health priority, Geneva 2012.

WHO, Therapeutic patient education. Continuing education programs for health care providers in the field of prevention of chronic diseases, Copenhagen 1998.

\section{Anna Mirczak: Selected therapeutic education needs of people with dementia and their families}

\section{Summary}

Dementia according to the ICD-10 classification is a syndrome of symptoms caused by chronic or progressive brain disease that manifests itself in disorders of higher cortical functions such as memory, thinking, orientation, comprehension, counting, language usage and ability to learn and evaluate. Despite the fact that dementia is not only a characteristic disease of the aging process, the risk of its developing is increasing significantly with age. Dementia is an incurable chronic disease, classified as a major geriatric problem that leads to a series of negative physical, psychological and social consequences. The person with dementia must 
be equipped in the way of therapeutic education with the knowledge and skills necessary for effective self-management (diagnosis and monitoring of symptoms, active attitude and full involvement in the therapeutic process, adaptation to disease and coping with its consequences, medication adherence etc.). Dementia is progressive which means that person's ability to remember, understand, communicate and reason gradually declines. In the last stage of dementia, the patient needs a total care. Caregivers are usually patient's family so there is a strong need for supporting them by therapeutic education including: nursing care, pain management, burnout prevention, social and physical rehabilitation. It's important to remember that dementia cannot be cured, but through health education it can be effectively controlled. The aim of the study was to present problems and needs of therapeutic education patient with dementia and their caregivers.

Key words: dementia, therapeutic education, older person, informal care 